\title{
Iron-reducing bacteria accumulate ferric oxyhydroxide nanoparticle aggregates that may support planktonic growth
}

\author{
Birgit Luef ${ }^{1,2}$, Sirine C Fakra ${ }^{1,3}$, Roseann Csencsits ${ }^{2}$, Kelly C Wrighton ${ }^{1}$, \\ Kenneth H Williams ${ }^{4}$, Michael J Wilkins ${ }^{5}$, Kenneth H Downing² ${ }^{2}$ Philip E Long ${ }^{4}$, \\ Luis R Comolli ${ }^{2}$ and Jillian F Banfield ${ }^{1,6}$ \\ ${ }^{1}$ Department of Earth and Planetary Science, University of California, Berkeley, Berkeley, CA, USA; \\ ${ }^{2}$ Lawrence Berkeley National Laboratory, Life Sciences Division, Berkeley, CA, USA; ${ }^{3}$ Lawrence Berkeley \\ National Laboratory, Advanced Light Source, Berkeley, CA, USA; ${ }^{4}$ Lawrence Berkeley National Laboratory, \\ Earth Sciences Division, Berkeley, CA, USA; ${ }^{5}$ Pacific Northwest National Laboratory, Biological Sciences \\ Division, Richland, WA, USA and ${ }^{6}$ Department of Environmental Science, Policy and Management, \\ University of California, Berkeley, Berkeley, CA, USA
}

\begin{abstract}
Iron-reducing bacteria (FeRB) play key roles in anaerobic metal and carbon cycling and carry out biogeochemical transformations that can be harnessed for environmental bioremediation. A subset of FeRB require direct contact with $\mathrm{Fe}(\mathrm{III})$-bearing minerals for dissimilatory growth, yet these bacteria must move between mineral particles. Furthermore, they proliferate in planktonic consortia during biostimulation experiments. Thus, a key question is how such organisms can sustain growth under these conditions. Here we characterized planktonic microbial communities sampled from an aquifer in Rifle, Colorado, USA, close to the peak of iron reduction following in situ acetate amendment. Samples were cryo-plunged on site and subsequently examined using correlated twoand three-dimensional cryogenic transmission electron microscopy (cryo-TEM) and scanning transmission X-ray microscopy (STXM). The outer membranes of most cells were decorated with aggregates up to $150 \mathrm{~nm}$ in diameter composed of $\sim 3 \mathrm{~nm}$ wide amorphous, Fe-rich nanoparticles. Fluorescent in situ hybridization of lineage-specific probes applied to rRNA of cells subsequently imaged via cryo-TEM identified Geobacter spp., a well-studied group of FeRB. STXM results at the Fe $L_{2,3}$ absorption edges indicate that nanoparticle aggregates contain a variable mixture of $\mathrm{Fe}(\mathrm{II})-$ $\mathrm{Fe}(\mathrm{III})$, and are generally enriched in $\mathrm{Fe}$ (III). Geobacter bemidjiensis cultivated anaerobically in the laboratory on acetate and hydrous ferric oxyhydroxides also accumulated mixed-valence nanoparticle aggregates. In field-collected samples, FeRB with a wide variety of morphologies were associated with nano-aggregates, indicating that cell surface $\mathrm{Fe}$ (III) accumulation may be a general mechanism by which FeRB can grow while in planktonic suspension.

The ISME Journal (2013) 7, 338-350; doi:10.1038/ismej.2012.103; published online 4 October 2012

Subject Category: geomicrobiology and microbial contributions to geochemical cycles

Keywords: iron-reducing bacteria; biomineralization; correlative microscopy; cryo-transmission electron microscopy; STXM; X-ray absorption spectroscopy
\end{abstract}

\section{Introduction}

Microbial precipitation and dissolution of minerals are fundamentally important in global biogeochemical cycling. In the subsurface, biologically induced

Correspondence: LR Comolli, Lawrence Berkeley National Laboratory, Life Sciences Division, Berkeley, CA, USA.

E-mail: lrcomolli@lbl.gov

or JF Banfield, Department of Earth and Planetary Sciences, Department of Environmental Science, Policy, and Management, University of California, Berkeley, 369 McCone Hall, Berkeley, CA, 94720, USA.

E-mail: jbanfield@berkeley.edu

Received 17 April 2012; revised 30 July 2012; accepted 30 July 2012; published online 4 October 2012 mineralization and dissolution are often coupled to changes in redox state and can alter solution chemistry, aquifer porosity and permeability (Ehrlich and Newman, 2009).

In natural systems, Fe(III) minerals can be microbiologically reduced by strictly anaerobic or facultative Fe-reducing bacteria (FeRB) using a wide range of organic compounds as electron donors or by using $\mathrm{H}_{2}$ (Ehrlich and Newman, 2009). The ability to use $\mathrm{Fe}(\mathrm{III})$ as a terminal electron acceptor is widespread across the domains Bacteria and Archaea. Geobacter metallireducens (strain GS-15), Geobacter sulfurreducens (strains KN400 and PCA), Shewanella oneidensis MR-1 and Shewanella putrefaciens (strains 200 and ATCC 8071) are the best- 
studied Fe(III)-reducing bacteria (see reviews by Mahadevan et al., 2001; Weber et al., 2006; Fredrickson et al., 2008 and references therein). Results indicate that for dissimilatory growth on Fe(III) minerals, Geobacter species require direct contact with insoluble Fe(III) oxide surfaces (Nevin and Lovley, 2000). In Geobacter spp., motility enables contact with $\mathrm{Fe}(\mathrm{III})$ oxides (Childers et al., 2002), which cells may reduce via conductive 'nanowires' that provide conduits for electron transfer (Reguera et al., 2005). Diverse periplasmic and outer-surface $c$-type cytochromes in Geobacter species also play key roles in extracellular electron transfer to Fe(III) (Lloyd et al., 1999; Ding et al., 2006; Leang et al., 2010; Qian et al., 2011). In contrast to other Fe(III)-reducing species, such as Shewanella, Geobacter cannot produce soluble electron shuttles to reduce Fe(III) minerals (Nevin and Lovley, 2000).

Prior studies have documented Fe-bearing minerals associated with cell surfaces. In the case of iron-oxidizing bacteria, nanoparticle aggregates accumulate following enzymatic oxidation of Fe(II) (Beveridge, 1989; Schädler et al., 2009; Comolli et al., 2011). In experiments where $S$. oneidensis MR-1 were incubated with ferrihydrite, a correlation was noted between the location of cell surfaceattached Fe-rich mineral aggregates and the outermembrane cytochrome MtrC, showing that these particles serve as the terminal electron acceptor (Reardon et al., 2010). However, the extent to which the cells actively accumulate these aggregates is unknown. In fact, direct association of Fe(III)-rich nanoparticle aggregates with FeRB cell surfaces has not been reported in natural systems.

Geobacter are typically reported as the dominant planktonic FeRB around the peak of iron reduction in field experiments where acetate is added to groundwater for in situ biostimulation (Anderson et al., 2003; Holmes et al., 2007; Wilkins et al., 2009). Thus, the question arises of how do FeRB that require contact with Fe-oxide surfaces for respiration proliferate as planktonic cells.

Ultrastructural information from FeRB recovered during the period of iron reduction from field biostimulation experiments may provide insight into how these organisms grow in suspension. The few prior ultrastructural studies on FeRB generally used conventional transmission electron microscopy (TEM) methods and targeted cells grown in pure culture (see, for example, Glasauer et al., 2001; Shelobolina et al., 2007). Traditional fixation and dehydration methods cause significant artifacts that can be eliminated by using cryogenic TEM (cryoTEM; see review by Milne and Subramaniam, 2009). Frozen hydrated samples, which are not stained, are imaged using low-dose techniques to minimize radiation damage and preserve structures in a 'nearnative' state. Cryo-TEM provides two-dimensional (2D) images, including fairly high-dose, high signalto-noise ratio views of selected areas. Cryogenic electron tomography provides three-dimensional (3D) ultrastructural information regarding cell organization and associations with inorganic phases at a resolution up to $\sim 4 \mathrm{~nm}$ (Comolli et al., 2009, 2011).

Here, we characterized groundwater planktonic FeRB from the uranium-contaminated aquifer sampled during in situ acetate amendment at the Department of Energy's Rifle Integrated Field Research Challenge (IFRC) site in Rifle, Colorado, USA. Our work differs from prior ultrastructural characterization efforts targeting natural subsurface microbial consortia in that samples were cryoplunged directly on site immediately after sampling. This step minimizes post-collection alteration, including cell damage. Cells and cell-associated minerals were analyzed using 2D and 3D cryo-TEM, high-resolution TEM, energy-dispersive spectroscopy (EDS) and scanning transmission X-ray microscopy (STXM). In addition, confocal laser scanning microscopy (CLSM) was performed on cells labeled with a Geobacter-specific fluorescence in situ hybridization (FISH) probe. This combination of microscopy and spectroscopy tools provided insight into the structure and composition of minerals associated with FeRB and uncovered a mechanism by which Geobacter may obtain energy during planktonic growth.

\section{Materials and methods}

Injection gallery design, operation and sampling The 'Super 8' acetate amendment field experiment was conducted at the Rifle IFRC site, Colorado, USA during August and September 2010. The experimental flow cell comprised 10 injection wells and 21 monitoring wells, with 2 monitoring wells located $\sim 5 \mathrm{~m}$ up-gradient of the region of injection (Supplementary Figure 1). Acetate and bromide (both as the sodium salt) were injected and dispersed into the wells (Williams et al., 2011). Acetate was added as a carbon source and electron donor to stimulate acetate-oxidizing microorganisms over the course of the 25-day injection period starting 23 August 2010, with bromide used as the conservative tracer. Acetate-amended ( $50 \mathrm{~mm}$, Sigma Aldrich, St Louis, MO, USA) and bromide-amended (20 mM, Sigma Aldrich) groundwater was injected into the subsurface at rates designed to achieve target aquifer concentrations of 5 and $2 \mathrm{~mm}$, respectively. Groundwater geochemistry was monitored throughout the experiment (Williams et al., 2011). For all analyses, groundwater from well CD-01 was sampled from 26 August 2010 to 7 September 2010 every 2 to 3 days.

\section{Specimen preparation in the field}

To prepare cryo-TEM samples on site, we used a simple portable cryo-plunge device (Comolli et al., 2012). For cryo-TEM and STXM, aliquots of $5 \mu \mathrm{l}$ groundwater sample were deposited onto 200 mesh 
lacey carbon-coated formvar $\mathrm{Cu}$ grids (Ted Pella Inc., Redding, CA, USA). Grids were manually blotted with filter paper and plunged into liquid ethane or propane at liquid nitrogen temperature, and then stored in liquid nitrogen until further analysis. For correlative FISH and TEM, samples were placed on pretreated, customized TEM nickel finder grids (Maxtaform Finder Grid Style H7, $63 \mu \mathrm{m}$ pitch, 400 mesh; SPI Supplies, West Chester, PA, USA), as described before (Knierim et al., 2011). Before use, both types of TEM grids were exposed to shortwave ultraviolet light for $30 \mathrm{~min}$ to improve sample deposition onto the grid. A total of 10 and $250 \mathrm{~nm}$ colloidal gold particles (BBInternational, Cardiff, UK) were put on TEM grids for cryo-TEM and for correlative FISH and TEM, respectively, and allowed to dry before sample collection.

In addition, for STXM experiments, groundwater from well CD-01 sampled 8 days after the start of acetate amendment was filtered onto a $0.2-\mu \mathrm{m}$ hydrophilic polyethersulfone filter (Pall Corporation, Port Washington, NY, USA). The filter was flash frozen in liquid nitrogen and stored at $-80{ }^{\circ} \mathrm{C}$ until measurements.

\section{The $2 D$ and $3 D$ cryo-TEM}

Imaging was performed on a JEOL JEM-3100 FFC TEM (JEOL Ltd, Akishima, Tokyo, Japan) equipped with a field emission gun electron source operating at $300 \mathrm{kV}$, an Omega energy filter (JEOL), a cryotransfer stage and a Gatan 795 2Kx2K CCD camera (Gatan Inc., Pleasanton, CA, USA). The stage was cooled with liquid nitrogen to $80 \mathrm{~K}$ during acquisition of all data sets.

In order to have a statistically relevant survey of cell sizes and morphologies, over 240 images were recorded using magnifications of $15-40 \mathrm{kx}$, giving a pixel size of $1.5-0.68 \mathrm{~nm}$ at the specimen. A total of 21 high-resolution cryo-TEM images $(80-200 \mathrm{kx}$, pixel size $0.35-0.122 \mathrm{~nm}$ ) of the nano-aggregates were acquired. Underfocus values ranged from 6.4 to $14 \pm 0.5 \mu \mathrm{m}$ for whole-cell imaging, and 20$374 \mathrm{~nm}$ for high-resolution cryo-TEM. Energy filter widths were typically $28 \pm 2 \mathrm{eV}$. The same grids used for cryo-TEM were freeze-dried and then used for further analyses by EDS.

A total of 10 tomographic data sets of cells with associated mineral aggregates were acquired. Tomographic tilt series were acquired under low-dose conditions, typically over an angular range between $+65^{\circ}$ and $-65^{\circ}, \pm 5^{\circ}$, with increments of $2^{\circ}$. Between 57 and 88 images were recorded for each tilt series, acquired semiautomatically with the program Serial-EM (http://bio3d.colorado.edu/) adapted to JEOL microscopes.

For tilt series data sets, all images were collected using nominal magnifications of 20 or $40 \mathrm{kx}$, corresponding to a pixel size of 1.2 and $0.68 \mathrm{~nm}$ at the specimen, respectively. Underfocus values ranged between $6 \pm 0.5 \mu \mathrm{m}$ and $12 \pm 0.5 \mu \mathrm{m}$, and energy filter widths were $\sim 28 \mathrm{eV}$. For all data sets the maximum dose used per complete tilt series was $\sim 150 \mathrm{e}^{-} \AA^{-2}$, with typical values of $\sim 100 \mathrm{e}^{-} \AA^{-2}$.

All tomographic reconstructions were obtained with the program Imod (http://bio3d.colorado.edu/; Kremer et al., 1996). The software Image $1.38 \mathrm{x}$ (NIH, http://rsb.info.nih.gov/ij/; Collins, 2007) was used for analysis of the 2D image projections. Volume rendering and image analysis of tomographic reconstructions were computed using the open source program ParaView (http://www. paraview.org/). All movies were created with the open source package ffmpeg (http://www.ffmpeg.org/). Adobe Photoshop CS5.1 was used to adjust contrast in the images and to insert calibrated scale bars into images.

\section{FISH and CLSM}

For FISH, frozen samples on TEM grids were fixed in paraformaldehyde solution ( $2 \%$ final concentration) while slowly thawing and then dehydrated as described in Knierim et al. (2011). To test whether the cells examined by cryo-TEM were Geobacter spp., an oligonucleotide probe GEO3-B, targeting rRNA genes, labeled with Cy3 was applied (Richter et al., 2007). Hybridization was performed on fixed samples, following a method previously described in Richter et al. (2007), with incubation at $46^{\circ} \mathrm{C}$ for $3 \mathrm{~h}$ and washing at $48^{\circ} \mathrm{C}$ for $20 \mathrm{~min}$. Hybridizations were counterstained with 4,6-diamidino-2-phenylindole (DAPI) DNA stain $\left(1 \mu \mathrm{g} \mathrm{ml}^{-1}\right.$ final concentration).

CLSM was performed on a Carl Zeiss Inc. LSM 710 Zen 2010, Release Version 6.0 software (Carl Zeiss MicroImaging Inc., Thornwood, NY, USA), equipped with Argon (458, 488 and $514 \mathrm{~nm}$ ) and HeNe $(594,543$ and $633 \mathrm{~nm}$ ) lasers and a diode $45-30$ $(405 \mathrm{~nm})$. The diode $(405 \mathrm{~nm})$ was used for DAPI signals (bandpass filters 410-495). CY3-labeled bacteria were detected by using the $514 \mathrm{~nm}$ laser line (bandpass filters 540-680). A Plan-Apochromat 100x/1.4 oil DIC (Zeiss) lens was used. Positively labeled bacteria were imaged and their positions on the TEM finder grids were marked.

Following CLSM, the grids were unmounted, washed in Milli-Q water (Millipore, Billerica, MA, USA), and then in pure ethanol and air dried. Subsequently, the bacteria analyzed by CLSM were imaged on a JEOL JEM-3100 FFC transmission electron microscope (using conditions as described above).

CLSM image stacks were processed with Imaris image processing and manipulation software (Bitplane AG, Zurich, Switzerland) and are presented as 2D maximum intensity projections.

TEM lattice fringe imaging, high-angle annular darkfield scanning TEM and EDS

TEM lattice fringe imaging, selected area electron diffraction and spatially resolved elemental analysis of cells on dried cryo-TEM samples were carried out 
on a JEOL 2100-F $200 \mathrm{kV}$ Field-Emission Analytical TEM equipped with Oxford INCA EDS X-ray detection system (Oxford Instruments, Abingdon, UK) at the Molecular Foundry at Lawrence Berkeley National Laboratory (Berkeley, CA, USA). High-angle annular dark-field scanning TEM images and X-ray elemental line scans were acquired with a 1-nm probe at both 120 and $200 \mathrm{kV}$. The specimens were tilted $10^{\circ}$ toward the X-ray detector to optimize the X-ray detection geometry. Collection time was $300 \mathrm{~s}$ for each line scan.

\section{STXM}

STXM analyses were performed on the following samples: (1) groundwater samples (8 days after the start of acetate amendment) on cryo-TEM grids; (2) $\sim 1 \mu \mathrm{l}$ of filtered groundwater deposited onto a $\mathrm{Si}_{3} \mathrm{~N}_{4}$ window (Silson, Ltd, Blisworth, UK) and air-dried, just before measurements; and (3) Geobacter culture samples (as described in the Laboratory cultures of Geobacter section). STXM measurements were carried out on beamlines 11.0.2 and 5.3.2.1 of the Advanced Light Source, Lawrence Berkeley National Laboratory (Kilcoyne et al., 2003). These microscopes employ a Fresnel zone plate lens (25 nm outer zones) to focus a monochromatic X-ray beam onto the sample. The sample is raster-scanned in $2 \mathrm{D}$ through the fixed beam and transmitted photons are detected via a phosphor scintillator-photomultiplier assembly. The image contrast relies on core electron excitation by X-ray absorption (Stöhr, 1992; Kirz et al., 1995). $\mathrm{X}$-ray images recorded at energies just below and at the $\mathrm{Fe} \mathrm{L}_{3}$ absorption edge were converted into optical density (OD) images and used to derive elemental maps $\left(\mathrm{OD}=\ln \left(I_{0} / I\right)\right.$, where $I_{0}$ is the incident X-ray intensity and $I$ is the transmitted intensity through the sample). Image sequences (that is, stacks) recorded at energies spanning the $\mathrm{Fe} \mathrm{L}_{2,3}$ edges $(700-735 \mathrm{eV})$ were used to obtain near-edge X-ray absorption fine structure (NEXAFS) spectra from regions of interest. $\mathrm{Fe} \mathrm{L}_{2,3}$ edges NEXAFS spectra are sensitive to $\mathrm{Fe}$ oxidation state and local bonding environment (de Groot, 1994). The relative amplitude of the two absorption peaks at the $\mathrm{Fe}_{3}$ edge is roughly indicative of the relative proportions of Fe(II) (at $\sim 707.8 \mathrm{eV}$ ) and Fe(III) (at $\sim 709.5 \mathrm{eV}$ ) present in the region of interest (van Aken and Liebscher, 2002). Iron NEXAFS spectra were compared with spectral libraries of reference compounds. Fe(III) standards included ferrihydrite 2 l, lepidocrocite, goethite, akaganeite, $\mathrm{FeCl}_{3}$ and hematite $\left(\alpha-\mathrm{Fe}_{2} \mathrm{O}_{3}\right)$. Mixed-valence Fe standard included magnetite $\left(\mathrm{Fe}_{3} \mathrm{O}_{4}\right)$. Fe(II) references included pyrite, pyrrhotite, $\mathrm{FeCl}_{2}$, biotite, siderite and vivianite. Fe L spectra (spectral shape, energy shift and intensity) are diagnostic of a specific Fe form in relationship to reference spectra, and hence our interpretation is limited by the relevance of our standards and other published spectra. All measurements were performed at ambient temperature under helium at pressure $<1 \mathrm{~atm}$. The theoretical spatial and spectral resolutions were $30 \mathrm{~nm}$ and $\pm 0.1 \mathrm{eV}$, respectively. Beam-induced damage was checked and not observed under our experimental conditions. The main $\mathrm{Fe}_{3}$ resonance of the ferrihydrite $2 \mathrm{~L}$ standard set at $709.5 \mathrm{eV}$ was used for relative calibration of the Fe spectra. All data were processed with the aXis2000 software (AP Hitchcock, an IDL-based analytical package, http://unicorn. mcmaster.ca).

Laboratory cultures of Geobacter

Standard anaerobic techniques were used throughout the laboratory studies (Balch and Wolfe, 1976; Balashova and Zavarzin, 1980). In order to obtain cell abundance comparable to that of the field samples and sufficient for visualization by cryoTEM, pure cultures of Geobacter bemidjiensis were grown anaerobically at $25^{\circ} \mathrm{C}$ using acetate $(10 \mathrm{~mm})$ as the carbon source and electron donor and fumarate $(40 \mathrm{~mm})$ as the electron acceptor with basal bicarbonate buffer (80 $\mathrm{N}_{2} / 20 \mathrm{CO}_{2}$; vol:vol; Caccavo et al., 1994). Cells were harvested in mid log phase (OD 0.25) via centrifugation $(4000 \mathrm{~g} ; 10 \mathrm{~min})$, washed once, and resuspended in $10 \mathrm{ml}$ of $30 \mathrm{~mm}$ phosphate buffer, working in an anaerobic glove bag. Cryo-TEM was conducted on the harvested cells to verify that nano-aggregates were not present at the start of the experiment.

The cell suspension was anoxically and aseptically added to $30 \mathrm{~mm}$ phosphate-buffered ( $\mathrm{pH}$ 7.1) fresh water media with $\mathrm{N}_{2}$ headspace amended with $10 \mathrm{~mm}$ acetate and $25 \mathrm{~mm}$ hydrous ferric oxyhydroxides (HFO; Lovley and Phillips, 1986). Freshwater basal medium contained the following (in grams per liter of deionized $\mathrm{H}_{2} \mathrm{O}$ ): $\mathrm{NaH}_{2} \mathrm{PO}_{4}, 0.38$; $\mathrm{Na}_{2} \mathrm{HPO}_{4}, 0.97 ; \mathrm{NH}_{4} \mathrm{Cl}, 0.25 ; \mathrm{KCl}, 0.1 ; \mathrm{DL}$ vitamins, $10 \mathrm{ml}$; and DL trace minerals, $10 \mathrm{ml}$ (Lovley and Phillips, 1988). A killed control was run in parallel. Cultures were maintained at $25^{\circ} \mathrm{C}$ in the dark. Fe(II) production and total $\mathrm{Fe}$ were monitored using the ferrozine assay for each treatment (Lovley and Phillips, 1988).

Samples for cryo-TEM and STXM were taken at the beginning of the experiment, and then 7.7 and 13.7 days after the start of the experiment. For STXM, $1 \mathrm{ml}$ of sample was flash frozen under anoxic conditions in liquid nitrogen and kept frozen at $-80^{\circ} \mathrm{C}$. Before analysis, $\sim 1 \mu$ l of the thawed sample was placed between two silicon nitride windows and sealed. Handling was carried out in an anaerobic glove box and the sample kept under anoxic conditions until measurements.

\section{Results}

Geochemistry

Groundwater samples were collected from well CD-01 (Figure 1). Injection of the acetate resulted 


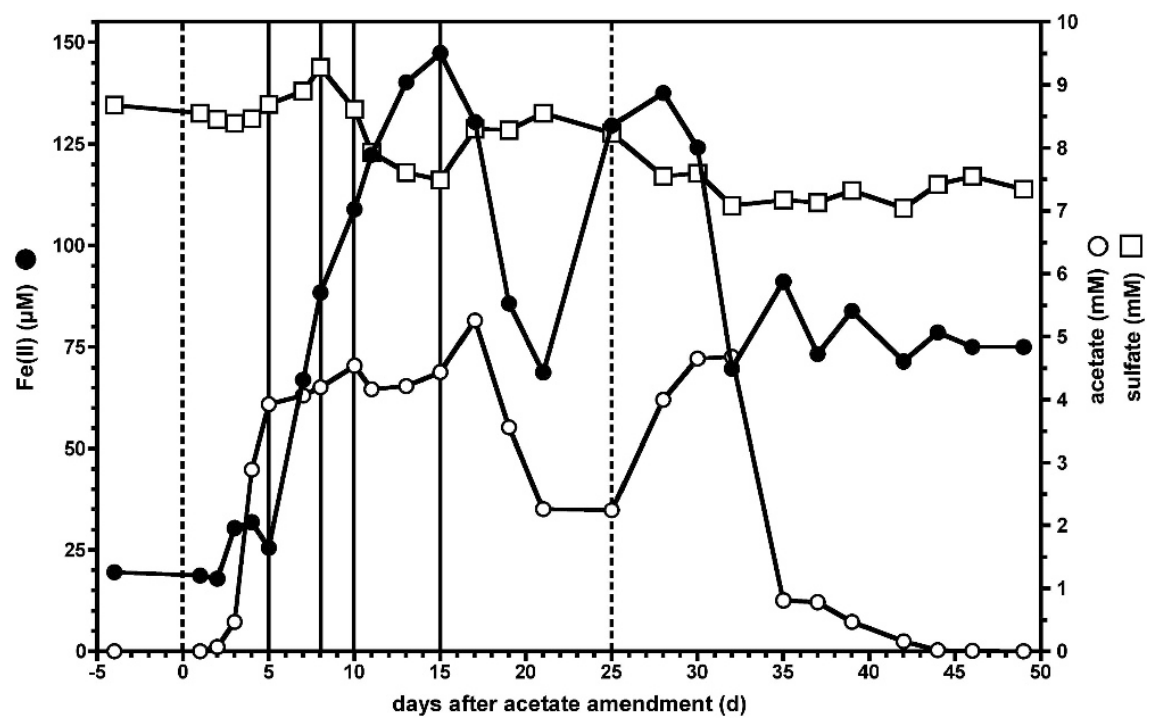

Figure 1 Changes in Fe(II), acetate and sulfate concentrations with time in well CD-01 during the Super 8 experiment at the Department of Energy's Rifle Integrated Field Research Challenge site in Rifle, Colorado, USA. Vertical dashed lines indicate beginning and end of the acetate amendment to the subsurface. The vertical solid lines indicate the collection dates for samples analyzed by cryo-TEM and related methods as reported in this paper. Note that the decrease in acetate concentration between days 18 and 24 is because of a 6-day gap between two acetate injection periods.

in a rapid increase in Fe(II). Sulfate concentrations stayed stable during the experiment, indicating minimal sulfide production during the sampling period. No sulfides were detected via STXM.

\section{Bacteria-mineral spatial relationship}

Cryo-TEM observations were exclusively based on groundwater aliquots instantly frozen at the field site. Samples collected after 8 days of acetate amendment were used for extensive ultrastructural characterization because this time point correlated with an increase in microbial abundance in the subsurface (data not shown). In addition, some observations were made for samples collected after 5, 10 and 15 days of acetate amendment. Cryo-TEM imaging of samples collected 8 and 15 days after the start of acetate amendment contained FeRB decorated with nano-aggregates.

Of the 252 planktonic groundwater cells investigated via 2D and 3D cryo-TEM, 187 were decorated with nanoparticle aggregates up to $150 \mathrm{~nm}$ in diameter (Figure 2a and Supplementary Figure 2). Aggregates were composed of $2.9 \pm 0.59 \mathrm{~nm}$ diameter $(n=30$, minimum diameter $=1.9 \mathrm{~nm}$, maximum diameter $=4.1 \mathrm{~nm})$ of individual nanoparticles (Figures 2b-d). The number and size of nanoaggregates covering the surface of individual cells varied greatly. Some cells exhibited very few small nano-aggregates, whereas others were almost entirely covered (Supplementary Figure 2). Cells varied in both shape (cocci, comma or rod shaped) and size (Table 1). All bacteria had a Gram-negativelike cell wall consisting of an inner membrane, an outer membrane and a peptidoglycan layer within a periplasmic space (Figure 2). The periplasm had a variable thickness ranging between 12 and $46 \mathrm{~nm}$, averaging $30 \mathrm{~nm}$ (Table 1). Some of the cells had flagella (Figure 2a), but pili were not observed. The contact area of the nano-aggregates to the cell surface and the volume of the nano-aggregates were determined for three of the cells for which tomographic data were available (Table 2). Two cells were chosen that were found during dominant iron reduction and therefore represent average cells regarding the cell surface area covered by nanoaggregates. In addition, one cell with smaller and fewer nano-particles attached to its outer membrane was encountered. Typically, between $4 \%$ and $15 \%$ of the cell surface area was covered by nanoaggregates.

The 3D reconstructions established that all aggregates were located outside of the cell wall (Figure 3). Aggregates adhered to the outer membrane, and in some cases, the interface was nearly flat (Supplementary Movie 1). Individual slices from $3 \mathrm{D}$ reconstructions suggest a physical connection between the nano-aggregates and the periplasmic space (Figure 3b). The TEM image resolution was sufficient to image lattice periodicities with a spacing of $\sim 0.3 \mathrm{~nm}$, but only one crystalline region was observed (Figure 4). Selected area electron diffraction patterns from the nano-aggregates exhibited no defined rings or spots.

\section{Identification of bacteria}

Hybridization of oligonucleotide probes to samples on cryo-TEM finder grids showed that the majority of the bacteria in the samples collected 8 and 15 days after acetate amendment were Geobacter spp. (Figure 5). The dominance of Geobacter was 




Figure 2 Cryo-TEM 2D projections of planktonic bacteria collected from the subsurface during the Super 8 experiment. Nanoparticle aggregates are attached to the outer membrane of these bacteria. (a) Image of an entire single cell. (b-d) Magnified regions of cell surfaces showing nano-aggregates attached to the outer membrane of the cells. CA, putative chemotaxis apparatus (see, for example, Comolli et al., 2011); F, flagellum; IM, inner membrane; OM, outer membrane; P, peptidoglycan.

Table 1 Measurements of cell sizes and inner to outer membrane spacing for groundwater bacteria with nanoparticle aggregates attached to their cell surface

\begin{tabular}{lccc}
\hline & $\begin{array}{c}\text { Cell length } \\
(\mathrm{nm})\end{array}$ & $\begin{array}{c}\text { Cell width } \\
(\mathrm{nm})\end{array}$ & $\begin{array}{c}\text { IM-OM distance } \\
(\mathrm{nm})\end{array}$ \\
\hline $\begin{array}{l}\text { Range } \\
\text { Average (s.d.) }\end{array}$ & $\begin{array}{c}818-2859 \\
1813(440)\end{array}$ & $\begin{array}{c}304-791 \\
521(127)\end{array}$ & $\begin{array}{c}12-46 \\
(6.5)\end{array}$ \\
\hline
\end{tabular}

Abbreviations: IM, inner membrane; OM, outer membrane. A total of 41 cells were measured. The s.d. values are shown in brackets. supported by $16 \mathrm{~S}$ rRNA and proteomic results, which revealed that a single Geobacter strain closely related to G. bemidjiensis ( $>97 \%$ similarity) dominated the community (accounting for $62 \%$ and $38 \%$ of the bacterial community 8 and 15 days after acetate amendment, respectively; MJ Wilkins et al., unpublished data). FISH-labeled bacteria (Figures $5 \mathrm{a}$ and $\mathrm{b}$ ) were imaged by CLSM and their positions on the grids were recorded. TEM analysis showed that Geobacter cells identified by FISH and imaged using CLSM had aggregates attached to their cell walls (Figures 5c and d). 
Table 2 Nano-aggregates

Bacterium A

Contact surface of nano-aggregates to the cell $\left(\times 10^{5} \mathrm{~nm}^{2}\right)$

Cell surface area covered by nano-aggregates (\%)

Volume of nano-aggregates $\left(\times 10^{7} \mathrm{~nm}^{3}\right)$

Number of Fe atoms available for the cell $\left(\times 10^{8}\right)$

Measurements and calculations are based on three bacterial reconstructions shown in Supplementary Figure 3. Bacterium A is shown in Figure 3. For FeOOH a density of $3.9 \mathrm{~g} \mathrm{~cm}^{-3}$ was assumed.

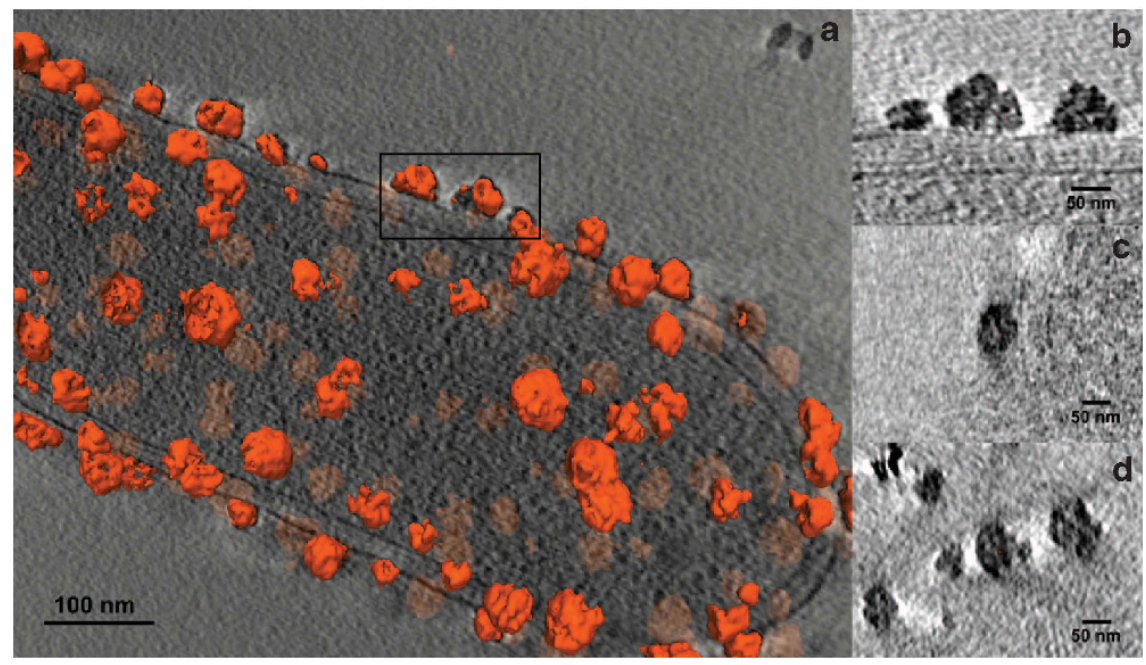

Figure 3 The 3D reconstruction of a bacterium decorated with nano-aggregates. (a) A single slice through the center of a tomographic reconstruction of a bacterium with 3D volume rendering of nano-aggregates (orange) attached to the cell wall. Slices through nanoaggregates of the 3D reconstruction shown within the box in (a) and cut (b) parallel to the long axis of the cell, (c) orthogonal to the long axis of the cell, and (d) parallel to the cell surface.

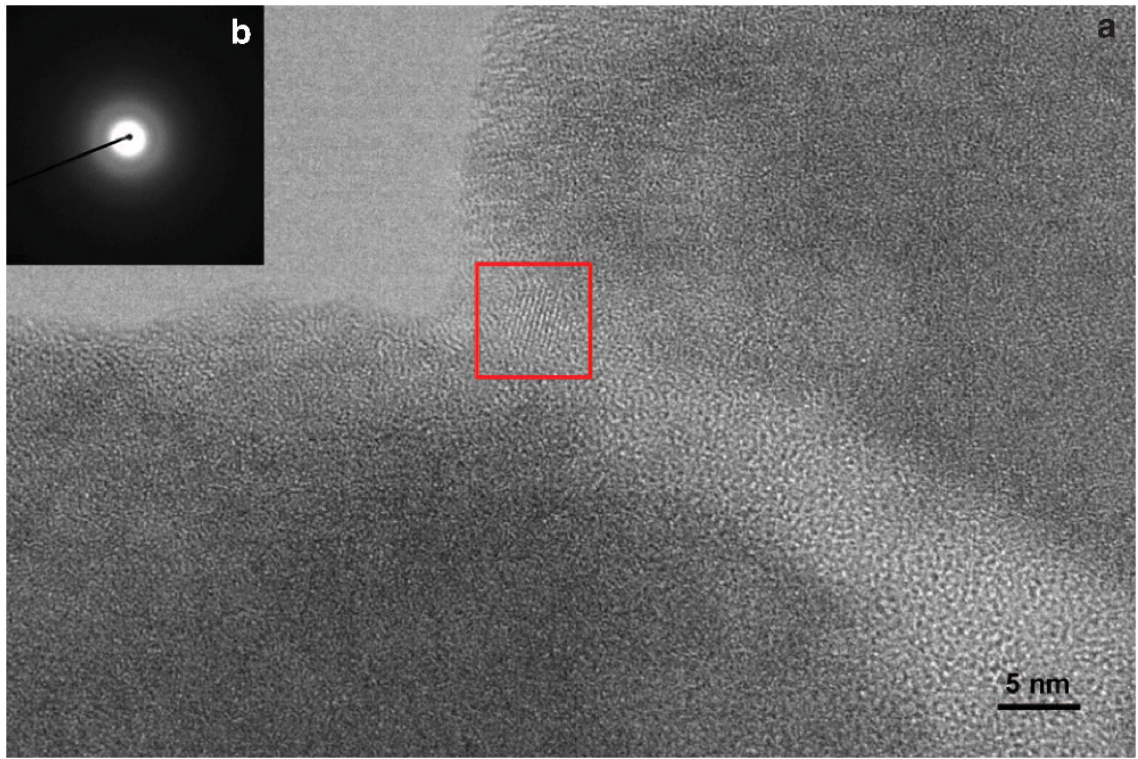

Figure 4 Structure of nano-aggregates. (a) TEM lattice fringe image of a nano-aggregate. Red box highlights the only region of crystalline structure within any nano-aggregate. (b) Representative selected area electron diffraction (SAED) pattern from nano-aggregates attached to a cell surface displaying diffuse diffraction rings indicating the amorphous nature of the nano-aggregates. 


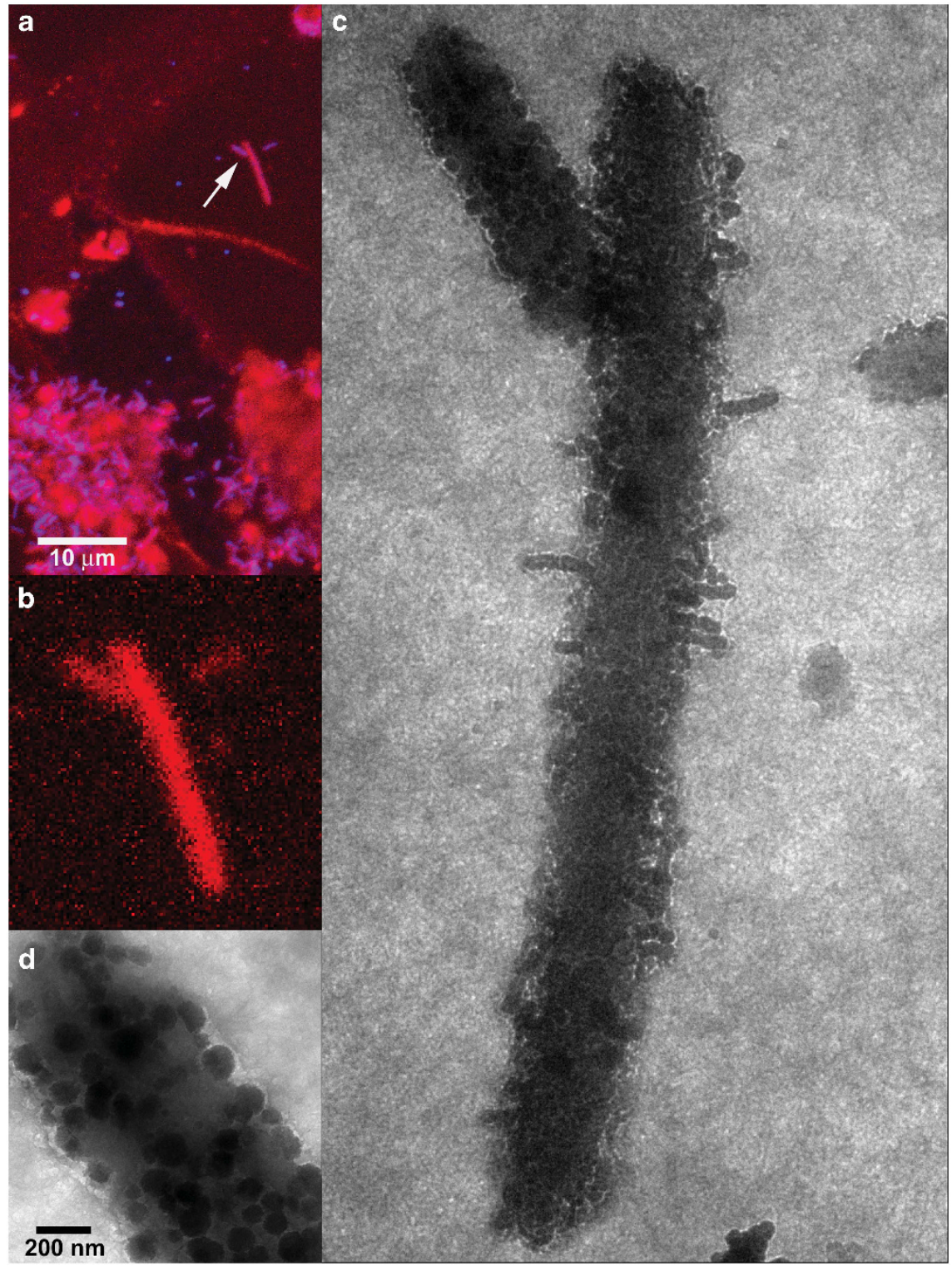

Figure 5 Correlative FISH and cryo-TEM. (a) Epifluorescence image of planktonic cells on a TEM grid positively labeled with Geobacter probe (Geo3 B) in red; DAPI in blue. (b) Close up of positively labeled Geobacter cells in red. (c) TEM defocused diffraction image of the same Geobacter cells as in (b) with aggregates of nanoparticles attached to the outer membrane imaged after FISH labeling. (d) Close up of nano-aggregates attached to the outer membrane of the FISH-labeled Geobacter cell. Because of thawing and dehydration processes, cells imaged by CLSM and then by TEM do not preserve ultrastructural details.

\section{Elemental composition of aggregates}

A total of 35 nanoparticle aggregates were analyzed for elemental composition with EDS line scans. The aggregates contained primarily $\mathrm{Fe}$ and $\mathrm{O}$, with smaller amounts of $\mathrm{V}$, Ca and $\mathrm{Si}$, and traces amounts of $\mathrm{P}, \mathrm{S}, \mathrm{K}$ and $\mathrm{Mg}$ (Figure 6). STXM elemental mapping at $\mathrm{C} \mathrm{K}, \mathrm{K} \mathrm{K}, \mathrm{Ca}_{3}, \mathrm{O} \mathrm{K}, \mathrm{V} \mathrm{L}_{3}$ and $\mathrm{Fe}_{3}$ edges showed that the aggregates primarily contained $\mathrm{Fe}$ and $\mathrm{O}$, with smaller amounts of $\mathrm{Ca}$ and $\mathrm{V}$ and traces of K (Figure 7). Si, P, S and Mg were not investigated by STXM.

Fe valence state of aggregates

Fe $\mathrm{L}_{2,3}$ NEXAFS spectra collected on cell surfaceattached nano-aggregates showed mixed-valence
Fe(II)-Fe(III) (Figure 8). The Fe(II)/Fe(III) ratio varied from one aggregate to another. Of the 29 cell surface-attached individual nano-aggregates measured by STXM on 13 planktonic cells, 21 were mixed-valence Fe, with high proportion of Fe(III), 3 were mostly Fe(II) and 5 were primarily Fe(III). A representative average spectrum from all nanoaggregates present on a cell shown in Figure 7a is displayed in Figure 8. This spectrum exhibits a lower $\mathrm{Fe}(\mathrm{II}) / \mathrm{Fe}(\mathrm{III})$ ratio than pure magnetite $\left(\mathrm{Fe}_{3} \mathrm{O}_{4}\right)$, and does not match published spectra of maghemite $\left(\gamma-\mathrm{Fe}_{2} \mathrm{O}_{3}\right)$, the oxidation product of magnetite (Bernard et al., 2010). In aggregate-free regions, a small, Fe(II)-rich background level was consistently detected. 

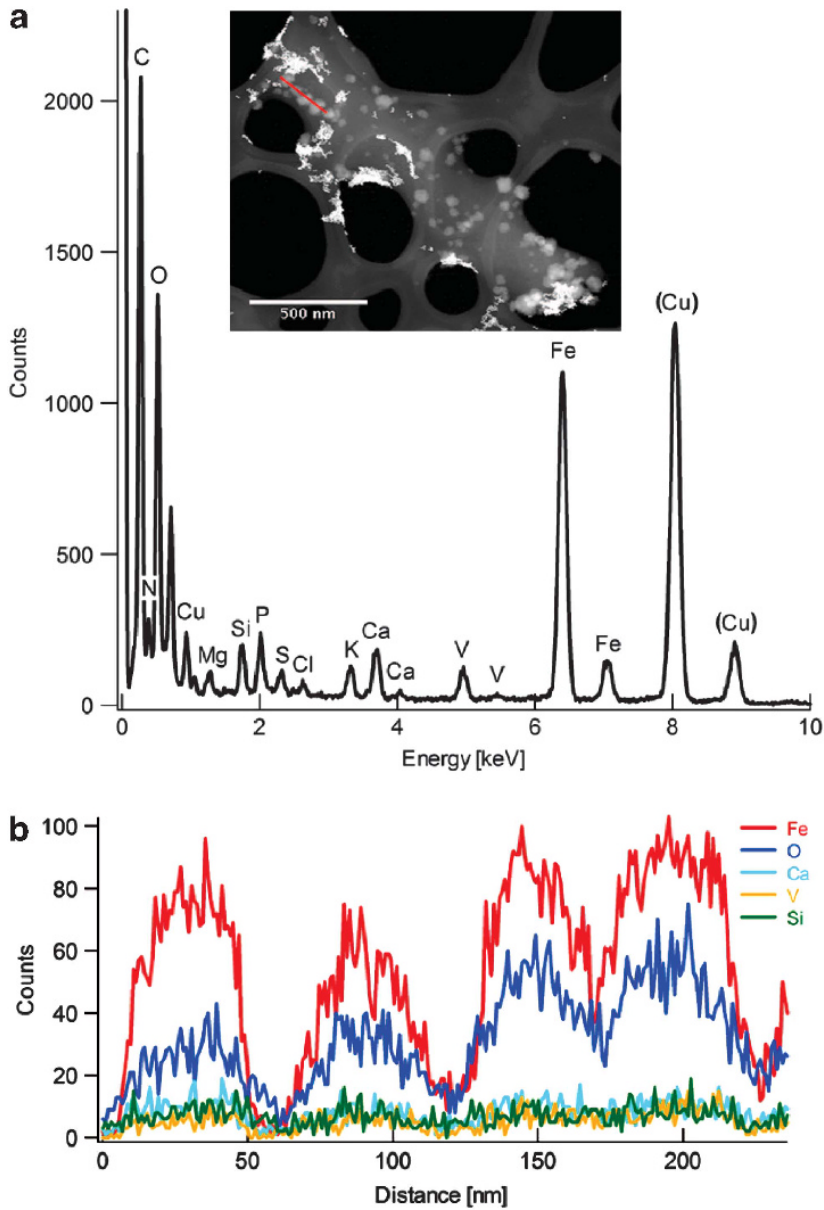

Figure 6 Energy-dispersive X-ray spectra from nano-aggregates attached to a bacterium. High-angle annular dark-field scanning TEM (HAADF-STEM) image of a bacterium with nano-aggregates attached to its cell surface. The red line indicates region of the line scan. Bacterium is supported by a carbon-coated lacey Formvar film. Bright white signals represent added gold colloids. (a) X-ray EDS sum spectrum of the line scan of nano-aggregates. $\mathrm{C}$ peak derived mainly from the cell. $\mathrm{Cu}$ peak and part of the $\mathrm{C}$ peak originated from the carbon-coated formvar $\mathrm{Cu}$ grids used for sample preparation. (b) EDS line scans of the five most abundant elements, $\mathrm{Fe}, \mathrm{O}, \mathrm{Ca}, \mathrm{V}$ and $\mathrm{Si}$, within the nano-aggregates.

\section{Confirmation of environmental results via laboratory experiment}

We verified that $G$. bemidjiensis cells actively reducing HFO coupled to acetate oxidation accumulate nanoparticle aggregates on their surfaces during a laboratory batch experiment. No nanoaggregates were observed on cell surfaces over the first 5.8 days of the experiment. Over this period, aqueous $\mathrm{Fe}$ (II) values ranged from 0.2 to $11.13 \mathrm{~mm}$, indicating utilization of $42.7 \%$ of the available Fe(III). However, 1.9 days later (7.7 days from start of the experiment) nano-aggregates were observed on almost all cell surfaces (Figures $7 \mathrm{~b}$ and $\mathrm{c}$ ) and the aqueous $\mathrm{Fe}(\mathrm{II}) / \mathrm{Fe}(\mathrm{III})$ ratio was 1:1. After 6 days (13.7 days from the start of the experiment), when the percentage of reduced iron increased to $63.2 \%$, nano-aggregates could no longer be detected on cell surfaces.
STXM analysis at $\mathrm{Fe} \mathrm{L}_{2,3}$ edges of the 7.7-day G. bemidjiensis culture sample showed that cellattached nano-aggregates contained of a variable mixture of Fe(III) and Fe(II) (Figures 7c and 8). It was important to verify the oxidation state of $\mathrm{Fe}$ in the cell-associated particles in these experiments. Field samples were cryo-plunged at the time of collection; however, the oxidation state of the Fe may have changed during the field sampling process. The laboratory results confirm that mixed-valence $\mathrm{Fe}$ coexist in the nanoparticle aggregates, suggesting preservation of $\mathrm{Fe}$ oxidation state in the field samples.

\section{Discussion}

Both field-recovered and laboratory culture samples show that under certain conditions, Geobacter cells accumulate mixed-valence iron oxyhydroxide nanoparticle aggregates onto their surfaces. Given that the initial cell-associated nanoparticle aggregates contain only Fe(III) (in laboratory experiments) and that some aggregates contain mixed valence iron, we infer that the iron is being biologically reduced. This finding allows us to answer the question posed of how can cells that require direct access to Fe (III)bearing minerals survive in the planktonic state. We conclude that Geobacter collect ferric iron minerals, which they can use as a terminal electron acceptor to support growth while not attached to macroscopic ferric iron-bearing minerals. Such a process could supplement other proposed mechanisms that enable maintenance energy requirements to be met during planktonic growth of Geobacter, such as the capacitive behavior of extracytoplasmic $c$-type cytochromes expressed during growth on synthetic and sediment Fe(III) oxides (Esteve-Núñez et al., 2008).

The cryo-TEM images acquired from field samples clearly indicate a diversity of cell shapes and sizes (Supplementary Figure 2), suggesting that a broader range of bacteria than Geobacter accumulate ferric iron nanoparticle aggregates on their cell surfaces. Regardless of their specific identities, accumulation of ferric iron-rich minerals may be a broadly relevant strategy used by FeRB to support planktonic growth.

Ferric iron associated with colloidal material in the aquifer represents a plausible source for the $\mathrm{Fe}(\mathrm{III})$ observed to accumulate on the bacterial cell surfaces. Such colloids are a natural component of the clay-sized fraction $(<2 \mu \mathrm{m})$ of alluvial sediments, such as those comprising the Rifle aquifer, and are typically found as both detrital and authigenic grain coatings on primary minerals (for example, quartz). In most cases, coatings are well aggregated and bound to primary minerals by both electrostatic forces and cementing agents, such as iron oxides, carbonates and silica (McCarthy and Zachara, 1989). Otherwise stable colloidal aggregates may periodically become deflocculated or released to groundwater as a result of changes in 
FIELD
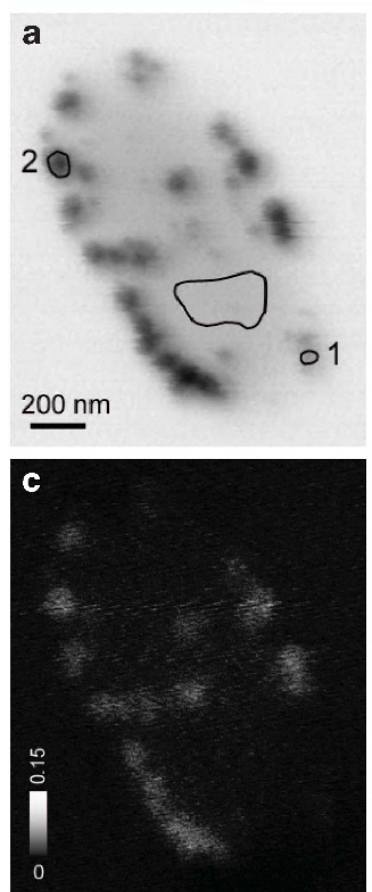

e

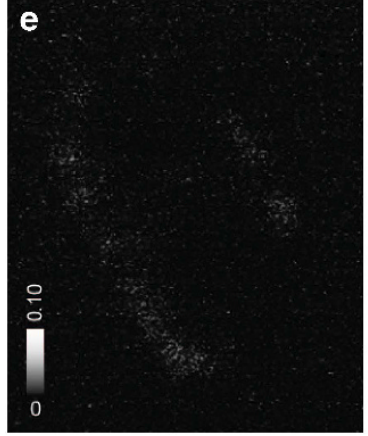

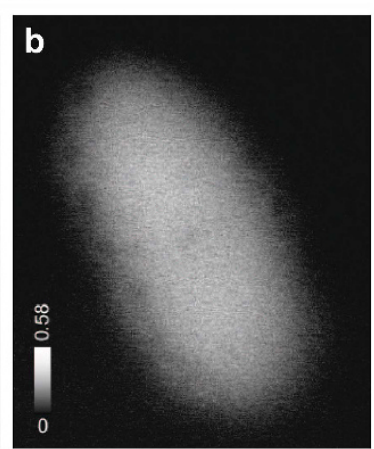
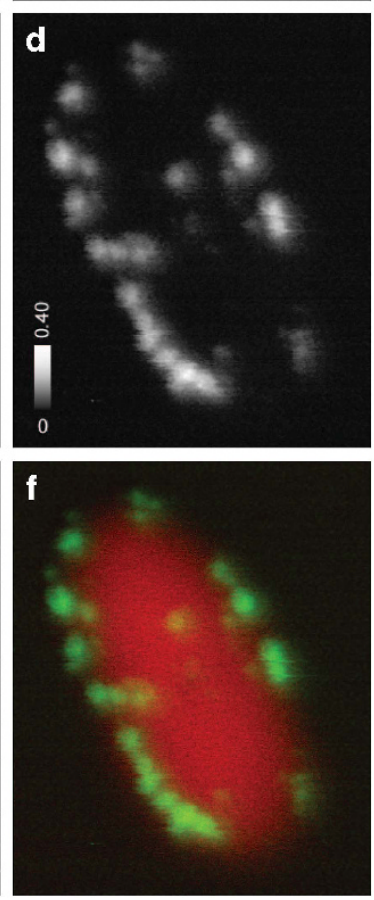

CULTURE
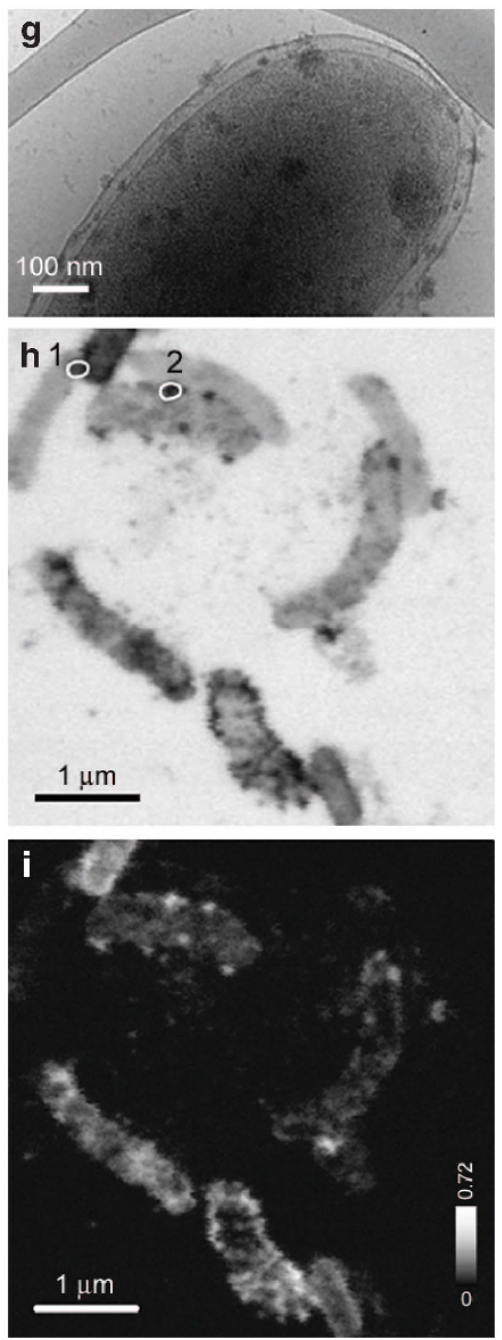

Figure 7 STXM analyses of nano-aggregates attached to planktonic bacteria collected from the subsurface during the Super 8 experiment (field, a-f) and to laboratory-grown G. bemidjiensis cells (culture, g-i). (a) STXM image at Fe $\mathrm{L}_{3} \mathrm{edge}(709.5 \mathrm{eV}$ ) of a planktonic cell decorated with nano-aggregates and corresponding (b) carbon, (c) calcium, (d) iron, (e) vanadium and (f) bicolor-coded C (in red) and Fe (in green) distribution maps. (g) 2D cryo-TEM image of a laboratory-grown G. bemidjiensis cell with nano-aggregates attached to the outer membrane. (h) STXM image at Fe $\mathrm{L}_{3}$ edge $(709.5 \mathrm{eV}$ ) of $G$. bemidjiensis cells with nano-aggregates and (i) Fe distribution map. Intensity scale bars are in optical density units.

local fluid chemistry (for example, pH, ionic strength, ionic composition) or decreases in aquifer redox status. Onset of iron-reducing conditions following acetate amendment is an example of the latter, wherein colloid release and/or deflocculation can accompany partial reductive dissolution of oxide cements (Thompson et al., 2006). Such a release mechanism has been demonstrated in laboratory batch incubations using a Rifle relevant Geobacter strain and similar to those reported here, where it was shown that acetate addition resulted in deflocculation of initially micron-sized ferrihydrite aggregates to nanometer-sized colloids (Tadanier et al., 2005).

Other mechanisms by which Geobacter transfer electrons to remotely located ferric iron-bearing minerals have been proposed. Specifically,
Geobacter species have the ability to sense and respond to iron minerals (Childers et al., 2002), and to transfer electrons to Fe(III) oxides over distances of multiple cell lengths via conductive pili (Reguera et al., 2005). This capacity has also been reported for other FeRBs, including Shewanella (Gorby et al., 2006). In the current study, we did not detect evidence for extensive pili production, possibly because the natural environmental growth conditions were not those that favor this particular pilimediated electron transfer mechanism.

Assuming that the nano-aggregates attached to the cell surface of FeRB accept electrons generated from acetate oxidation, we can use measurements from three tomographic data sets (for cells A, B and C in Supplementary Figure 3) to estimate the respiratory value of this resource. The electron-accepting 


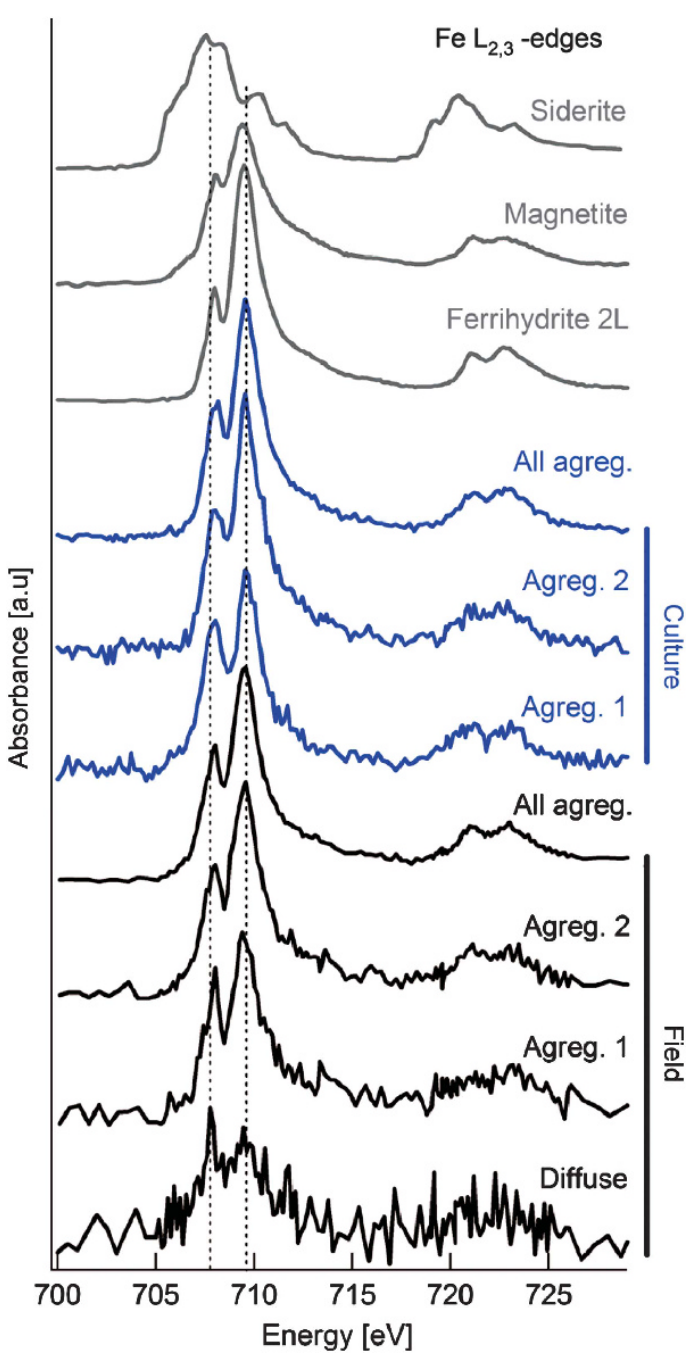

Figure $8 \mathrm{Fe} \mathrm{L} \mathrm{L}_{2,3}$ NEXAFS spectra of nano-aggregates attached to G. bemidjiensis cells (culture, in blue) and to a planktonic cell (field, in black). Spectra were obtained from selected areas pointed out in Figure 7a. For clarity, spectra from the diffuse and aggregate no. 2 areas were multiplied by a factor of 15 and 2 , respectively, and all spectra were shifted vertically. Fe standards (confirmed by XRD) are shown for comparison and include Fe(II) carbonate (siderite), Fe(III) oxyhydroxide (ferrihydrite) and mixed-valence magnetite $\left(\mathrm{Fe}_{3} \mathrm{O}_{4}\right)$. Vertical dashed lines are located at 707.8 and $709.5 \mathrm{eV}$.

capacity of the nano-aggregates varies significantly (Table 2 and Supplementary Figure 3). Bacterium A and $\mathrm{B}$ had sufficient $\mathrm{Fe}(\mathrm{III})$ aggregates to accept $1.38 \times 10^{-15} \mathrm{~mol}$ electrons, whereas aggregates associated with bacterium $C$ could accept $2.29 \times 10^{-16}$ mol electrons. Energy generated, in the form of a proton-motive force, could be used for ATP synthesis and cell maintenance or flagellar rotation.

Chemostat-grown $G$. sulfurreducens cells require an electron transfer of $1.19 \times 10^{-14} \mathrm{~mol}$ electrons per hour (Esteve-Núñez et al., 2005; Esteve-Núñez et al., 2008). Thus, nano-aggregates on bacteria A and $\mathrm{B}$ could support a maintenance metabolic rate for $\sim 7 \mathrm{~min}$, and bacterium $\mathrm{C}$ for $\sim 1 \mathrm{~min}$. The chemostat measurements for cells growing in relatively rich media likely overestimate the energy demand for cells growing in the natural environment, and hence these times may be underestimates.

The importance of flagellar-driven motility and chemotaxis along an Fe(II) gradient is documented in Geobacter spp. (Childers et al., 2002). One flagellar rotation consumes 1200 protons (Meister et al., 1987), 300 flagellar rotations occur per second (Bray, 2001), and the average speed of a bacterium is $25 \mu \mathrm{m} \mathrm{s}^{-1}$ (Berg et al., 2002). Using the number of protons generated by complete reduction of the ferric iron in the cell-attached nanoparticles, and assuming that all are devoted to flagellar rotation, bacteria A and B are motile over a distance of $57 \mathrm{~mm}$ (distances $\sim 25000$ and 32000 times the cell length of bacterium $\mathrm{A}$ and $\mathrm{B}$, respectively), and bacterium C $\sim 9.5 \mathrm{~mm}$. Although we acknowledge that these assumptions are difficult to verify for environmental bacteria, our calculations clearly support the notion that $\mathrm{Fe}(\mathrm{III})$ in the nano-aggregates could function as an electron sink from acetate oxidation and may represent a supporting life strategy for FeRB in an environment, where Fe(III) mineral surfaces may be abundant but spatially dispersed.

Microbial metal reduction is of great interest for environmental remediation (Lovley, 1993). Almost two decades ago, Lovley et al. (1991) proposed the use of indigenous dissimilatory iron-reducing microorganisms to catalyze the reduction of U(VI) in groundwater to insoluble U(IV). Results of the current study provide new insight into the planktonic growth mechanism of Geobacter, and help to explain how these bacteria proliferate to high numbers in the planktonic phase during acetate amendment for uranium bioreduction.

\section{Acknowledgements}

This research was funded by the Subsurface Biogeochemistry Program (SBR) Biological and Environmental Research (BER), Office of Science, US Department of Energy Grant Number: DE-SC0004733. We thank Cristina E Siegerist for help with image display, T Tyliszczak and ALD Kilcoyne for support at ALS BL11.0.2 and 5.3.2, respectively. The magnetite spectrum for STXM analysis was provided by $\mathrm{T}$ Tyliszczak. The Advanced Light Source, Molecular Foundry and the Rifle IFRC and ERSP Projects managed by Lawrence Berkeley National Laboratory (Berkeley, CA, USA) are supported by the Office of Basic Energy Sciences, Office of Science, US Department of Energy Contract No. DE-AC02-05CH11231.

\section{References}

Anderson RT, Vrionis HA, Ortiz-Bernad I, Resch CT, Long PE, Dayvault R et al. (2003). Stimulating the in situ activity of Geobacter species to remove uranium from the groundwater of a uranium-contaminated aquifer. Appl Environ Microbiol 69: 5884-5891. 
Balashova VV, Zavarzin GA. (1980). Anaerobic reduction of ferric iron by hydrogen bacteria. Microbiology 48: 635-639.

Balch WE, Wolfe RS. (1976). New approach to the cultivation of methanogenic bacteria: 2-mercaptoethanesulfonic acid (HS-CoM)-dependent growth of Methanobacterium ruminantium in a pressurized atmosphere. Appl Environ Microbiol 32: 781-791.

Berg JM, Tymoczko JL, Stryer L. (2002). Biochemistry, 5th edn, W. H. Freeman and Company: New York.

Bernard S, Benzerara K, Beyssac O, Brown GE Jr. (2010). Multiscale characterization of pyritized plant tissues in blueschist facies metamorphic rocks. Geochim Cosmochim Acta 74: 5054-5068.

Beveridge TJ. (1989). Role of cellular design in bacterial metal accumulation and mineralization. Annu Rev Microbiol 43: 147-171.

Bray D. (2001). Cell Movements: From Molecules to Motility, 2nd edn, Garland Pub.: New York.

Caccavo F Jr, Lonergan DJ, Lovley DR, Davis M, Stolz JF, McInerney MJ. (1994). Geobacter sulfurreducens sp. nov., a hydrogen-oxidizing and acetate-oxidizing dissimilatory metal-reducing microorganism. Appl Environ Microbiol 60: 3752-3759.

Chan CS, de Stasio G, Welch SA, Girasole M, Frazer B, Nesterova $M$ et al. (2004). Microbial polysaccharides template assembly of nanocrystal fibers. Science 303: 1656-1658.

Chan CS, Fakra SC, Edwards DC, Emerson D, Banfield JF. (2009). Iron oxyhydroxide mineralization on microbial polysaccharides. Geochim Cosmochim Acta 73: 3807-3818.

Chan CS, Fakra SC, Emerson D, Fleming EJ, Edwards KJ. (2011). Lithotrophic iron-oxidizing bacteria produce organic stalks to control iron mineral growth: Implications for biosignature formation. ISME $J \mathbf{5}$ : 717-727.

Childers SE, Ciufo S, Lovley DR. (2002). Geobacter metallireducens accesses insoluble Fe(III) oxide by chemotaxis. Nature 416: 767-769.

Collins TJ. (2007). ImageJ for microscopy. BioTechniques 43: 25-30.

Comolli LR, Baker BJ, Downing KH, Siegerist CE, Banfield JF. (2009). Three-dimensional analysis of the structure and ecology of a novel, ultra-small archaeon. ISME J 3: 159-167.

Comolli LR, Luef B, Chan CS. (2011). High-resolution 2D and 3D cryo-TEM reveals structural adaptations of two stalk-forming bacteria to an Fe-oxidizing lifestyle. Environ Microbiol 13: 2915-2929.

Comolli LR, Duarte R, Baum D, Luef B, Downing KH, Larson D et al. (2012). A portable cryo-plunger for onsite intact cryogenic microscopy sample preparation in natural environments. Microsc Res Tech 75: 829-836.

de Groot FMF. (1994). X-ray absorption and dichroism of transition metals and their compounds. J Electron Spectroscopy 67: 529-622.

Ding YR, Hixson KK, Giometti CS, Stanley A, EsteveNúñez A, Khare T et al. (2006). The proteome of dissimilatory metal-reducing microorganism Geobacter sulfurreducens under various growth conditions. Biochim Biophys Acta 1764: 1198-1206.

Ehrlich HL, Newman DK (eds). (2009). Geomicrobiology. CRC Press Taylor \& Francis Group: Boca Raton, FL, pp 606.
Esteve-Núñez A, Mary Rothermich M, Sharma M, Lovley D. (2005). Growth of Geobacter sulfurreducens under nutrient-limiting conditions in continuous culture. Environ Microbiol 7: 641-648.

Esteve-Núñez A, Sosnik J, Visconti P, Lovley D. (2008). Fluorescent properties of $c$-type cytochromes reveal their potential role as an extracytoplasmic electron sink in Geobacter sulfurreducens. Environ Microbiol 10: $497-505$.

Fortin D, Langley S. (2005). Formation and occurrence of biogenic iron-rich minerals. Earth-Sci Rev 72: 1-19.

Fredrickson JK, Romine MF, Beliaev AS, Auchtung JM, Driscoll ME, Gardner TS et al. (2008). Towards environmental systems biology of Shewanella. Nat Rev Microbiol 6: 592-603.

Glasauer S, Langley S, Beveridge TJ. (2001). Sorption of Fe (hydr)oxides to the surface of Shewanella putrefaciens: cell-bound fine-grained minerals are not always formed de novo. Appl Environ Microbiol 67: 5544-5550.

Gorby YA, Yanina S, McLean JS, Rosso KM, Moyles D, Dohnalkova A et al. (2006). Electrically conductive bacterial nanowires produced by Shewanella oneidensis strain MR-1 and other microorganisms. Proc Natl Acad Sci USA 103: 11358-11363.

Holmes DE, O'Neil RA, Vrionis HA, N'Guessan LA, OrtizBernad I, Larrahondo MJ et al. (2007). Subsurface clade of Geobacteraceae that predominates in a diversity of $\mathrm{Fe}(\mathrm{III})$-reducing subsurface environments. ISME J 1: 663-677.

James RE, Ferris FG. (2004). Evidence for microbialmediated iron oxidation at a neutrophilic groundwater spring. Chem Geol 212: 301-311.

Kilcoyne ALD, Tyliszczak T, Stelle WF, Fakra SC, Hitchcock P, Franck K et al. (2003). Interferometer-controlled scanning transmission X-ray microscopes at the Advanced Light Source. J Synchrotron Radiat 10: 125-136.

Kirz J, Jacobsen C, Howells M. (1995). Soft X-ray microscopes and their biological applications. Q Rev Biophys 28: 33-130.

Knierim B, Luef B, Wilmes P, Auer M, Webb RI, Comolli LR et al. (2011). Correlative microscopy for phylogenetic and ultrastructural characterization of microbial communities. Environ Microbiol Rep; e-pub ahead of print 22 August 2011; doi:10.1111/ j.1758-2229.2011.00275.x.

Kremer JR, Mastronarde DN, McIntosh JR. (1996). Computer visualization of three-dimensional image data using IMOD. J Struct Biol 116: 71-76.

Leang C, Qian X, Mester T, Lovley DR. (2010). Alignment of the $c$-type cytochrome OmcS along pili of Geobacter sulfurreducens. Appl Environ Microbiol 76: 4080-4084.

Lloyd JR, Blunt-Harris EL, Lovley DR. (1999). The periplasmic 9.6-kilodalton $\mathrm{C}$-type cytochrome of $\mathrm{Geo}$ bacter sulfurreducens is not an electron shuttle to Fe(III). J Bacteriol 181: 7647-7649.

Lovley DR, Phillips EJP. (1986). Organic matter mineralization with reduction of ferric iron in anaerobic sediments. Appl Environ Microbiol 51: 683-689.

Lovley DR, Phillips EJP. (1988). Novel mode of microbial energy metabolism: organic carbon oxidation coupled to dissimilatory reduction of iron or manganese. Appl Environ Microbiol 54: 1472-1480.

Lovley DR, Phillips EJP, Gorby YA, Landa ER. (1991). Microbial reduction of uranium. Nature 350: 413-415. 
Lovley DR. (1993). Dissimilatory metal reduction. Annu Rev Microbiol 47: 263-290.

Mahadevan R, Palsson BØ, Lovley DR. (2001). In situ to in silico and back: elucidating the physiology and ecology of Geobacter spp. using genome-scale modelling. Nat Rev 9: 39-50.

McCarthy J, Zachara J. (1989). ES\&T Features: Subsurface transport of contaminants. Environ Sci Technol 23: 496-502.

Meister M, Lowe G, Berg H. (1987). The proton flux through the bacterial flagellar motor. Cell 49: 643-650.

Milne JLS, Subramaniam S. (2009). Cryo-electron tomography of bacteria: progress, challenges and future prospects. Nat Rev Microbiol 7: 666-675.

Nevin KP, Lovley DR. (2000). Lack of production of electron-shuttling compounds or solubilization of Fe(III) during reduction of insoluble Fe(III) oxide by Geobacter metallireducens. Appl Environ Microbiol 66: 2248-2251.

Qian X, Mester T, Morgado L, Arakawa T, Sharma ML, Inoue $\mathrm{K}$ et al. (2011). Biochemical characterization of purified OmcS, a $C$-type cytochrome required for insoluble $\mathrm{Fe}(\mathrm{III})$ reduction in Geobacter sulfurreducens. Biochim Biophys Acta 1807: 404-412.

Reardon CL, Dohnalkova AC, Nachimuthu P, Kennedy DW, Saffarini DA, Arey BW et al. (2010). Role of outermembrane cytochromes MtrC and OmcA in the biomineralization of ferrihydrite by Shewanella oneidensis MR-1. Geobiology 8: 56-68.

Reguera G, McCarthy KD, Mehta T, Nicoll JS, Tuominen MT, Lovley DR. (2005). Extracellular electron transfer via microbial nanowires. Nature 435: 1098-1101.

Richter H, Lanthier M, Nevin KP, Lovley DR. (2007). Lack of electricity production by Pelobacter carbinolicus indicates that the capacity for Fe(III) oxide reduction does not necessarily confer electron transfer ability to fuel cell anodes. Appl Environ Microbiol 73: 5347-5353.
Schädler S, Burkhardt C, Hegler F, Straub KL, Miot J, Benzerara K et al. (2009). Formation of cell-ironmineral aggregates by phototrophic and nitrate-reducing anaerobic Fe(II)-oxidizing bacteria. Geomicrobiol J 26: 93-103.

Shelobolina ES, Coppi MV, Korenevsky AA, DiDonato LN, Sullivan SA, Konishi H et al. (2007). Importance of $C^{-}$ type cytochromes for U(VI) reduction by Geobacter sulfurreducens. BMC Microbiol 7: 16-30.

Stöhr J (eds). (1992). NEXAFS Spectroscopy. SpringerVerlag: Berlin, pp 403.

Suzuki T, Hashimoto H, Itadani A, Matsumoto N, Kunoh H, Takada J. (2012). Silicon and phosphorus linkage with iron via oxygen in the amorphous matrix of Gallionella ferruginea stalks. Appl Environ Microbiol 78: $236-241$.

Tadanier CJ, Schreiber ME, Roller JW. (2005). Arsenic mobilization through microbially mediated deflocculation of ferrihydrite. Environ Sci Technol 39: 3061-3068.

Thompson A, Chadwick OA, Boman S, Chorover J. (2006). Colloid mobilization during soil iron redox oscillations. Environ Sci Technol 40: 5743-5749.

van Aken PA, Liebscher B. (2002). Quantification of ferrous/ ferric ratios in minerals: new evaluation schemes of $\mathrm{Fe} \mathrm{L}_{2,3}$ electron energy-loss near-edge spectra. Phys Chem Miner 29: 188-200.

Weber KA, Achenbach LA, Coates JD. (2006). Microorganisms pumping iron: anaerobic microbial iron oxidation and reduction. Nat Rev Microbiol 4: 752-764.

Wilkins MJ, VerBerkmoes NC, Williams KH, Callister SJ, Mouser PJ, Elifantz $\mathrm{H}$ et al. (2009). Proteogenomic monitoring of Geobacter physiology during stimulated Uranium bioremediation. Appl Environ Microbiol 75: 6591-6599.

Williams KH, Long PE, Davis JA, Steefel CI, Wilkins MJ, N'Guessan AL et al. (2011). Acetate availability and its influence on sustainable bioremediation of uraniumcontaminated groundwater. Geomicro J 28: 519-539.

Supplementary Information accompanies the paper on The ISME Journal website (http://www.nature.com/ismej) 